\title{
Survey Of Student Anxiety Levels During The Covid-19 Pandemic
}

\author{
Imam Mahfud 1), Aditya Gumantan2) \\ Program Studi Pendidikan Olahraga \\ Fakultas Sastra dan Ilmu Pendidikan \\ ${ }^{1,2}$ Universitas Teknokrat Indonesia, Lampung, Indonesia \\ Email: ${ }^{1}$ imam_mahfud@ @eknokrat.ac.id, ${ }^{2}$ aditya.gumantan@teknokrat.ac.id
}

\begin{abstract}
The purpose of this study was to determine the level of anxiety students during the Covid-19 pandemic. This research method uses a survey with data collection techniques using a questionnaire given to 110 respondents. The scores obtained from the questionnaire were analyzed using quantitative descriptive analysis. Based on the results of the study, $36.4 \%$ felt very anxious, $34.1 \%$ felt anxious, $20.9 \%$ felt not anxious, and $9 \%$ felt very uneasy about this pandemic. At the level of fear during activities, 50\% felt afraid, $22.7 \%$ were not afraid, and $6.8 \%$ felt very unafraid. At the level of concern, 25\% of respondents felt very worried about the Covid-19 pandemic that was happening, $56.8 \%$ were worried, $11.4 \%$ were not worried, and $6.8 \%$ felt very unconcerned. Of the 110 respondents $83 \%$ did sports activities during the pandemic and $17 \%$ did not do sports activities. $65 \%$ of respondents know that anxiety affects the body's immunity 35\% do not know. This anxiety because of the fear of contracting this virus and it affects the learning process of students and the family economy will be disrupted.
\end{abstract}

Keywords: Survey, Anxiety, Covid-19

\section{Survei Tingkat Kecemasan Mahasiswa Selama Pandemi Covid-19 ABSTRAK}

Tujuan dari penelitian ini adalah untuk mengetahui tingkat kecemasan mahasiswa selama pandemi covid-19. Metode penelitian ini menggunakan survei dengan teknik pengambilan data dengan menggunakan angket yang diberikan ke 110 responden. Skor yang didapatkan dari angket dianalisis menggunakan analisis deskriptif kuantitatif. Berdasarkan hasil penelitian didapatkan hasil 36,4\% merasa sangat cemas, 34,1\% merasa cemas, 20,9\% merasa tidak cemas, dan 9\% merasa sangat tidak cemas dengan pandemi ini. Pada tingkat ketakutan saat beraktifitas terdapat $50 \%$ merasa takut, 22,7\% tidak takut, dan 6,8\% merasa sangat tidak takut. Pada tingkat khawatiran didapatkan $25 \%$ responden merasa sangat khawatir dengan pandemi covid-19 yang terjadi, 56,8\% merasa khawatir, 11,4\% tidak khawatir, dan 6,8\% merasa sangat tidak khawatir. Dari 110 responden $83 \%$ melakukan aktivitas olahraga selama pandemi dan $17 \%$ tidak melakukan aktifitas olahraga. 65\% responden mengetahui bahwa kecemasan berpengaruh terhadap imunitas tubuh 35 $\%$ tidak mengetahui. Kecemasan ini disebabkan karena rasa ketakutan akan tertular virus ini dan berdampak pada proses pembelajaran mahasiswa serta ekonomi keluarga akan terganggu.

Kata Kunci: Survei, Kecemasan, Covid-19

Info Artikel

Dikirim

Diterima

Dipublikasikan
: 23 September 2020

: 29 Oktober 2020

: 12 November 2020
(C) 2020 IKIP BUDI UTOMO MALANG

P-ISSN 2613-9421

E-ISSN 2654-8003

\footnotetext{
\ Alamat korespondensi: imam_mahfud@teknokrat.ac.id

Universitas Teknokrat Indonesia, J1. ZA. Pagar Alam No.9 -11, Labuhan Ratu, Kec. Kedaton, Kota Bandar Lampung,

Lampung 35132, Indonesia
} 


\section{PENDAHULUAN}

Corona merupakan virus yang sedang menjadi pandemi didunia dan telah menginveksi jutaan orang. Indonesia sendiri sesuai dengan data yang didapatkan dari Gugus Tugas Percepatan Penanganan Covid-19 per tangal 29 mei 2020 terdapat 2.216 orang positif terinveksi virus corona, dengan rincian 6.492 orang dinyatakan telah sembuh dan terdapat 1.520 orang meninggal. Kehadiran virus ini menyebabkan keresahan dan kecemasan di masyarakat.

Untuk menghindari agar tidak terjangkit virus ini masyarakat dihimbau untuk menghindari keramaian, mengkuti protokol kesehatan, tetap tenang dan tidak panik selama pandemi ini terjadi. Hal ini berdasarkan Keppres no 112020 tentang Penetapan Kedaruratan Kesehatan Masyarakat Corona Virus Disease 2019 pada poin kesatu Covid-19 sebagai penyakit yang menimbulkan kedaruratan kesehatan dalam masyarakat. berdasarkan Keppres 12 tahun 2020 tentang Penetapan Bencana Nonalam Penyebaran Corona Virus Disease 2019 (COVID-19) sebagai Bencana Nasional yang ditetapkan oleh Presiden pada tanggal 13 April 2020.

Salah satu cara agar terhindar dari terjangkitnya virus ini masyarakat dihimbau untuk tetap menjaga kesehatan dan meningkatkan imunitas tubuh. Dikarenakan pandemi ini, masyarakat akan cenderung mengalami kepanikan salah satunya dikarenakan kurangnya informasi yang mendalam tentang virus ini. Kecemasan merupakan keadaan emosional seseorang yang tidak menyenangkan, hal ini ditandai dengan respon psikofisiologis yang nampak sebagai antisipasi bahaya. Hal ini disebabkan oleh konflik intrapsikis (Dorland, 2010).

Masa pandemi covid-19 memberikan dampak pada masyarakat. Dampak dalam psikologis yaitu kecemasan karena virus sangat cepat menular dari orang yang sakit ke orang yang sehat (Fitria \& Ifdil, 2020). Dengan penularan virus yang sangat cepat dan jumlah korban jiwa yang meningkat semakin menambah tingkat kecemasan masyarakat. Dengan korban yang semakin bertambah ini berpengaruh besar terhadap kesehatan mental masyarakat.

Kehadiran virus ini membuat masyarakat menjadi mudah panik, was-was, cemas, hingga menimbulkan stres pada mereka. Perasaan yang berlebihan ini, karena masyarakat terlalu banyak menerima informasi sehingga menyebabkan 
masyarakat menjadi psikosomatik akibat pandemi covid-19. Psikosomatik adalah perwujudan rasa cemas yag berlebihan dengan perasaan tubuh menimbulkan gejala mirip covid-19. Padahal sebenarnya tubuh tidak terjangkit covid-19. Hal ini merupakan perwujudan dari kecemasan yang berlebihan (Ilpaj \& Nurwati, 2020).

Faktor kecemasan yang berlebihan ini akan mempengaruhi sikap seseorang dalam menghadapi pandemi covid-19(Setiawan et al., 2020). Kecemasan yang berlebihan akan menyebabkan seseorang mengalami stress. Stres adalah respon tubuh terhadap setiap kebutuhan tubuh yang terganggu. Hal ini akibat dari fenomena universal yang terjadi dan tidak dapat dihindari. Stres akan memberikan dampak secara nyata pada individu yaitu pada fisik, psikologis, intelektual, dan fisiologis. (Mayasari \& Pratiwi, 2009). Kecemasan merupakan suatu bentuk emosi negatif dengan adanya perasaan khawatir, perasaan selalu was-was, dan disertai dengan terjadinya peningkatan perubahan pada sistem jaringan (Nurseto, 2018).

Cemas adalah situasi yang terjadi dimana keadaan fisiologi dari tubuh seseorang seolah-olah merasa tercekik, akibatnya akan meningkatkan detak jantung yang berlebihan (Hengki et al., 2018). Kecemasan menjadi masalah psikologis yang muncul pada tiap individu. Keadaan itu sering tidak jelas tetapi kecemasan itu sendiri selalu dirasakan (Ayu et al., 2018)

Kecemasan merupakan keadaan perasaan yang tidak menyenangkan yang disertai dengan sensasi fisik yang akan menjadi peringatan pada seseorang terhadap bahaya. Keadaan ini sering tidak jelas dan sulit dideteksi dengan tepat, tetapi kecemasan itu sendiri selalu dapat dirasakan. Seseorang yang mengalami kecemasan cenderung selalu merasa khawatir akan kondisi dan keadaan buruk yang akan menimpanya (Nova et al., 2020). Kecemasan didefinisikan berupa perasaan kekhawatiran. Kecemasan menjadi bentuk peringatan pada individu tentang kemungkinan akan terjadinya suatu bahaya sehingga dapat disiapkan reaksi adaptif yang sesuai. Kecemasan berfungsi sebagai mekanisme pelindung ego, karena kecemasan akan memberikan sinyal bahwa ada bahaya. Jika tidak dilakukan tindakan yang sesuai maka bahaya itu akan meningkat hingga ego dikalahkan (Husdarta, 2010). Kecemasan yang berlebihan akan berdampak pada tingkah laku seseorang, seperti rasa ketakutan yang berlebihan. Hal ini akan berdampak sangat besar terhadap kehidupan seseorang baik kesehatan dan kinerja. 
Rasa cemas dapat dikurangi dengan tingkat pemahaman seseorang terhadap kondisi dan situasi permasalahan yang sedang dihadapi (Resti, 2014).

Dampak besar dari kecemasan yang berlebihan dapat mempengaruhi kondisi fisik. Karena saat seseorang mengalami kecemasan maka secara tidak langsung akan meningkatkan detak jantung pada dirinya. Akibat dari kecemasan selain berdampak pada psikologi juga akan mempengaruhi keadaan fisik seseorang (Junaidi \& Noor, 2010). Dampak ini berupa akan menyebabkan rasa pusing, sakit kepala, dan lain-lain (Annisa \& Ifdil, 2016). Dengan dampak fisik ini akan dapat mempengaruhi kinerja seseorang. Dampak ini juga dapat mempengaruhi keadaan iminutas seseorang, karena dengan rasa cemas akan merangsang peningkatan produksi hormon kortisol dalam tubuh. Hormon ini yang selanjutnya akan menekan imunitas tubuh (Hammad, 2011). Salah satu cara guna meningkatkan imunitas yaitu dengan berolahraga atau melakukan aktifitas fisik.

Kecemasan yang berlebihan juga akan menggangu proses pendidikan, karena rasa takut yang tinggi akibat sesuatu, seperti keadaan saat ini dengan adanya pandemi Covid-19. Karena ketakutan yang berlebihan akan beberapa hal ini akan mengganggu kejernihan dalam berfikir, daya ingat dalam belajar (Suardana \& Simarmata, 2013).

Sudah terdapat beberapa penelitian kecemasan terhadap covid 19 dalam berbagai bidang. Penelitian dari (Fitria et al., 2020) membahas tentang peran cognitive behavior therapy counseling yang dilakukan untuk mengatasi anxiety dalam masa pandemi covid-19. Penelitian dari (Fadli et al., 2020) yang membahas tentang faktor apa saja yang memepengaruhi kecemasan pada tenaga kesehatan dalam upaya pencegahan covid-19. Penelitian dari (Fitria \& Ifdil, 2020) yang membahas tentang kecemasan yang terjadi pada remaja saat covid-19. Dalam hal ini dari beberapa penelitian yang ada belum membahas tentang kecemasan pada mahasiswa. Dalam konteks ini, kesehatan mental mahasiswa penting dalam menunjang proses kegiatan sehari-hari khususnya dalam proses perkuliahan.

Berdasarkan pemaparan diatas, penelitian ini bertujuan untuk mendapatkan informasi terkait dengan kecemasan mahasiswa selama pandemi covid-19 terjadi. Dengan penelitian ini harapannya selain untuk mengetahui tingkat kecemasan 
mahasiswa, juga bertujuan untuk mengetahui dampak-dampak yang terjadi akibat kecemasan pada kehidupan dan proses pembelajaran mahasiswa.

\section{METODE}

Penelitian ini mengunakan metode deskriptif kualitatif. Deskriptif kualitatif adalah suatu metode atau cara yang digunakan oleh seorang peneliti untuk dapat menemukan teori terhadap penelitian. Penelitian deskriptif kualitatif digunakan untuk menerjemahkan data yang berkaitan erat dengan keadaan sosial, keterkaitan antar variabel yang terjadi serta hadirnya fakta yang ada beserta akibat yang ditimbulkannya (Mukhtar, 2013). Rancangan dalam penelitian ini dapat dilihat pada chart berikut ini:

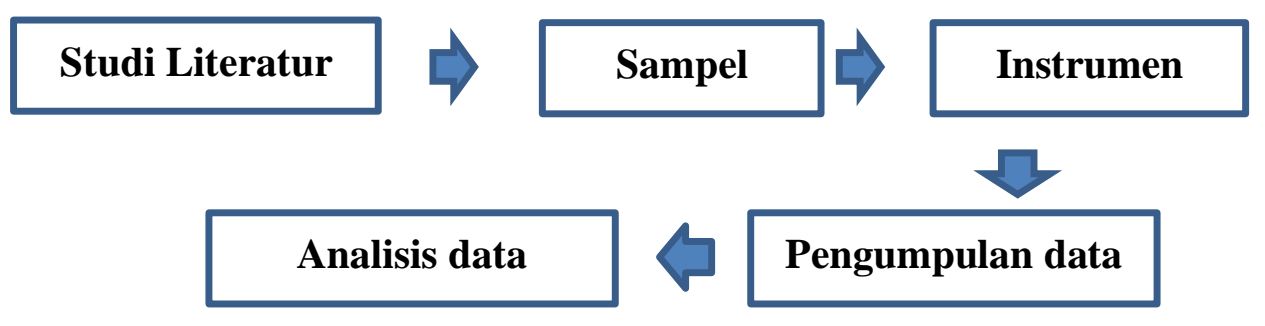

Gambar. 1. Diagram Alur Penelitian

Berikut penjelasan dari diagram alur tersebut:

1. Studi Literatur. Pada tahap ini Studi literatur yang dilakukan peneliti melakukan pencarian referensi dari berbagai berbagai sumber yang ada baik dari buku, arsip, artikel, dan jurnal, atau dokumen-dokumen yang relevan dan sesuai dengan permasalahan yang akan dikaji dalam penelitian. Informasi yang didapatkan dari studi literatur ini menjadi rujukan untuk memperkuat argumen yang ada.

2. Sampel. Tahap ini merupakan tahap awal dalam proses penelitian yang akan dilaksanakan. Sampel dalam penelitian ini adalah mahasiswa pada program studi Pendidikan Olahraga di Universitas Teknokrat Indonesia.

3. Instrumen. Instrumen dalam penelitian ini dengan menggunakan survei berdasarkan analisis dari studi literatur yang dilakukan. Survei ini menggunakan angket kecemasan dengan menggunakan media google form 
4. Pengumpulan Data. Setelah memberikan angket analisis kecemasan pada mahasiswa pendidikan olahraga selanjutnya data hasil penelitian dikumpulkan untuk selanjutnya akan dianalisis hasil yang didapatkan.

5. Analisis Data. Setelah data penelitian didapatkan selanjutnya data hasil penelitian tersebut dianalisis dengan metode deskriptif kualitatif untuk didapatkan hasil seberapa besar tingkat kecemasan yang dialami mahasiswa selama pandemi covid-19.

\section{HASIL DAN PEMBAHASAN}

Berdasarkan hasil penelitian yang dilaksanakan dengan mengunakan angket yang disebar 110 respoden yang terdiri dari klasifikasi jenis kelamin, usia terhadap mahasiswa. Hal ini dilakukan dengan tujuan untuk mengetahui sejauh mana tingkat kecemasan pada mahasiswa saat terjadi pandemi covid-19 beserta dampak yang dialaminya. Berdasarkan hasil penelitian yang dilakukan terdapat $36,4 \%$ merasa sangat resah dengan pandemi covid-19 yang terjadi, 34,1\% merasa resah, 20,5 tidak resah, dan 9\% merasa sangat tidak resah.

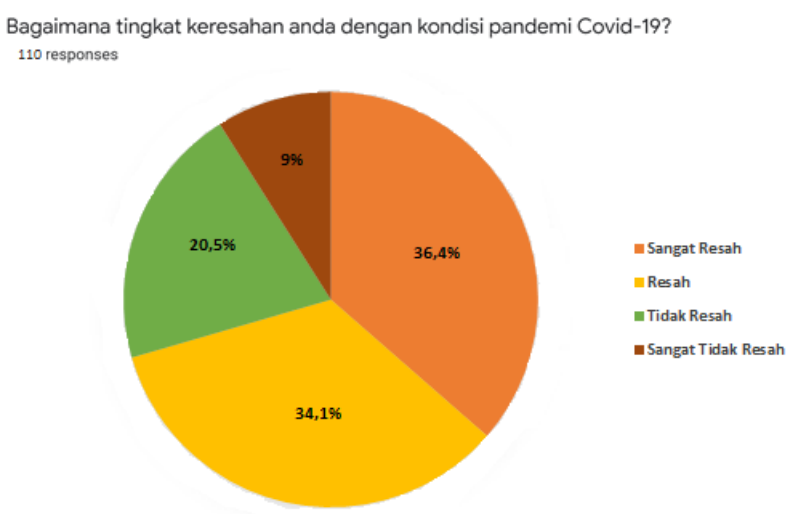

Gambar 2. Hasil angket tingkat kecemasan mahasiswa saat pandemi Covid-19

Berdasarkan hasil penelitian yang dilakukan, pada seseorang yang mengalami sangat resah saat terjadi pandemi covid-19 terjadi karena rasa khawatir dan takut tertular dikarenakan virus ini menyebar dengan cepat dan takut akan terdampak pada keluarga. Selain itu resah dan kwatir akan berdampak pada pendidikan yang terganggu dan berdampak pada ekonomi keluarga. Tingkat keresahan yang tinggi ini sesuai dengan penelitian yang dilakukan oleh (Fitria \& Ifdil, 2020) yaitu 
kecemasan pada remaja saat covid-19 dengan hasil kecemasan pada kategori sedang 43,9\% dan kategori tinggi 54\%. Untuk responden yang merasa tidak resah terdapat pernyataan bahwa responden akan selalu percaya dengan keadaan tubuh yang sehat, dan merasa akan baik-baik saja.

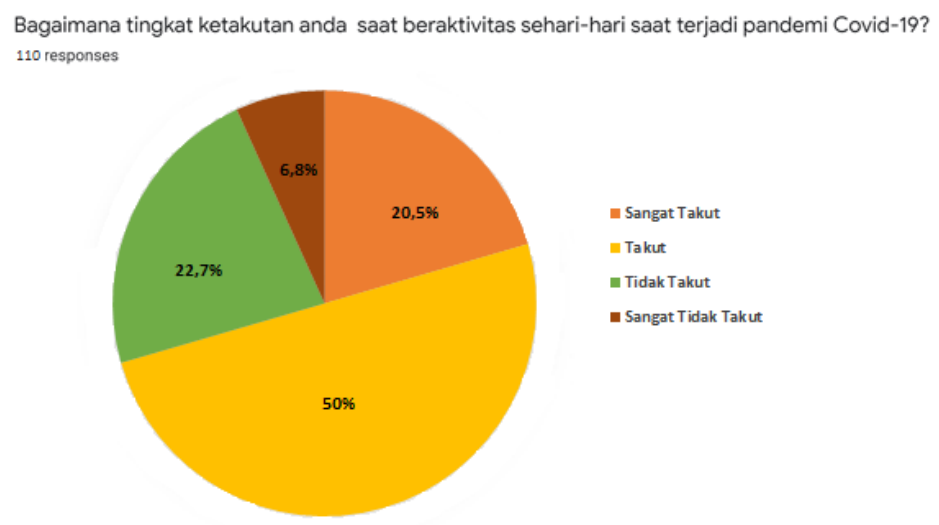

Gambar 3. Hasil angket tingkat ketakutan saat beraktifitas

Hasil penelitian yang di dapat dari 110 respoden tentang ketakutan saat beraktifitas sehari-hari mahasiswa saat terjadi pandemi covid-19 terdapat 20,5\% responden merasa sangat takut dengan pandemi covid-19 yang terjadi, 50\% merasa takut, $22,7 \%$ tidak takut, dan $6,8 \%$ merasa sangat tidak takut dengan pandemi covid-19.

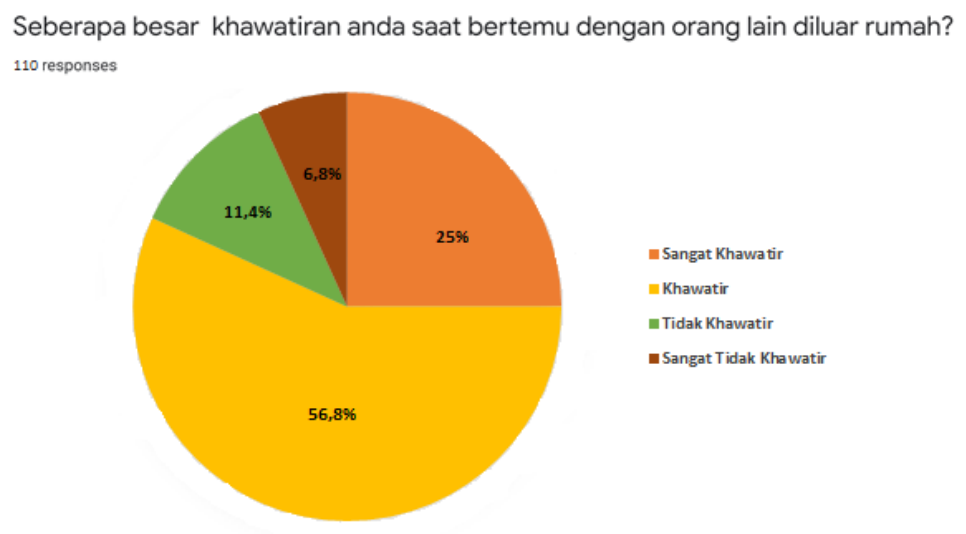

Gambar 4. Hasil angket tingkat kekhawatiran saat bertemu orang lain

Hasi penelitian yang di dapat dari 110 respoden tentang kekhawatiran saat bertemu orang lain terdapat $25 \%$ responden merasa sangat khawatir dengan pandemi covid-19 yang terjadi, 56,8\% merasa khawatir, 11,4\% tidak khawatir, dan 6,8\% merasa sangat tidak khawatir dengan pandemi covid-19. 
Untuk responden yang merasa tidak khawatir terdapat pernyataan bahwa "Kita sebagai manusia membutuhkan ssialisasi dengan orang lain, sehingga mau tidak mau kita harus selalu berhubungan dengan orang-orang diluar sana”. Responden juga menyadari bahwa virus ini sangat berbahaya, tetapi mereka tetap beraktivitas sesuai dengan protokol kesehatan yang dianjurkan oleh pemerintah.

Untuk responden yang merasa khawatir mereka beranggapan bahwa mereka merasa takut dan khawatir akan tertular covid-19 saat bersosialisasi dengan orang lain. Terdapat juga responden yang merasa takut dan was-was saat bertemu orang lain sehingga mereka cenderung takut untuk keluar rumah.

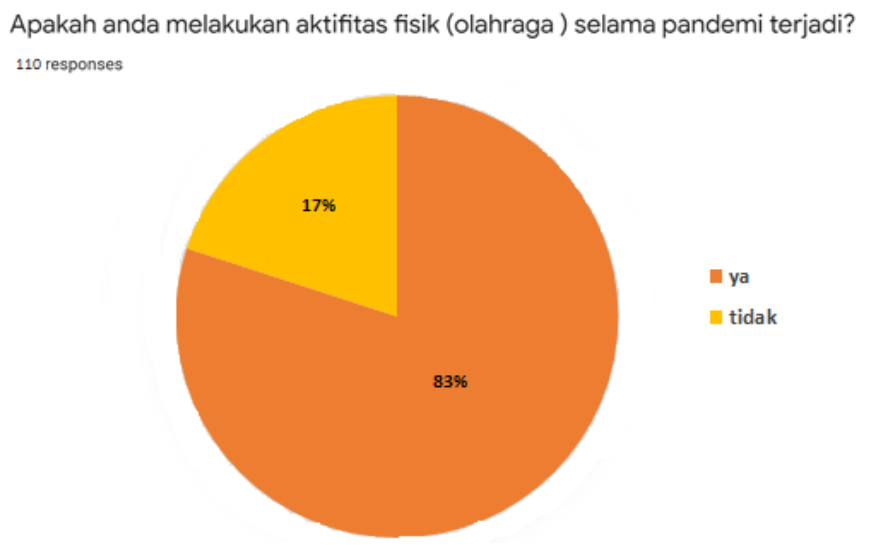

Gambar 5. Hasil angket olahraga selama pandemi

Hasil penelitian yang di dapat dari 110 respoden tentang kegiatan dan aktivitas fisik yang dilakukan selama pandemi terdapat $83 \%$ melakukan aktifitas fisik dan olahraga selama pandemi terjadi dan $17 \%$ tidak melakukan aktifitas olahraga.

Responden yang melakukan aktifitas fisik dan olahraga selama pandemi dilakukan dengan aktifitas olahraga ringan seperti joging disekitar rumah, skipping, push-up, sit-up. Hal ini dilakukan untuk tetap menjaga kondisi tubuh tetap fit dan kebugaran jasmani tetap terjaga. 


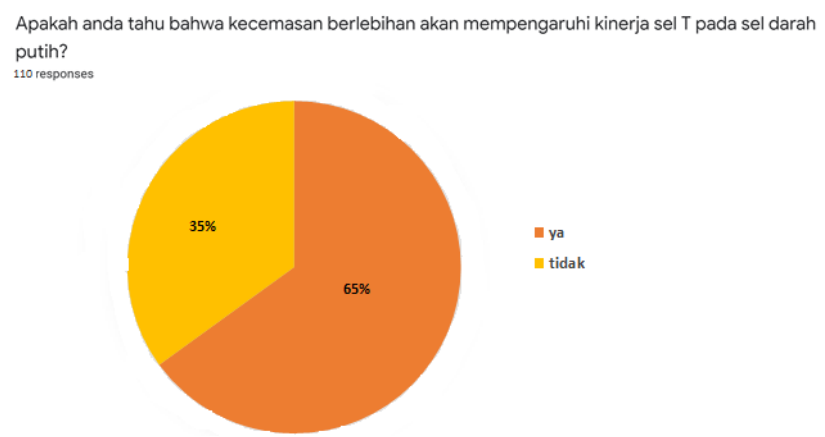

Gambar 5. Hasil angket pengetahuan mahasiswa tentang hubungan kecemasan dengan imunitas.

Hasil penelitian yang di dapat dari 110 respoden tentang pengetahuan mahasiswa terkait dengan pengaruh kecemasan yang berlebihan terhadap imunitas tubuh terdapat $65 \%$ mengetahui bahwa kecemasan berpengaruh terhadap imunitas. Mereka mengetahui bahwa kecemasan mempengaruhi imunitas dari berita di media cetak, online dan dari perkuliahan yang dilaksanakan mahasiswa. Terdapat 35\% tidak mengetahui bahwa kecemasan mempengaruhi imunitas.

Kecemasan akan berpengaruh terhadap imunitas tubuh, karena pikiran yang menyebabkan cemas akan meningkatkan produksi hormon kartisol dalam tubuh yang dapat mempengaruhi kinerja sel $\mathrm{T}$ dalam sel darah putih. Sel darah putih berperan dalam melawan pantogen yang masuk ke dalam tubuh. Apabila kinerja sel darah putih terganggu maka imunitas tubuh akan menurun dan berbahaya apalagi saat pandemi covid-19 ini terjadi (Gumantan et al., 2020). Untuk itu imunitas harus dijaga dengan olahraga yang teratur Olahraga merupakan bagian dari kehidupan serta salah satu dari kebutuhan jasmani yang penting bagi manusia (Mahfud \& Fahrizqi, 2020). Karena aktifitas fisik selain mempengaruhi, psikologi, kognitif, emosi, dan sosial. Aktifitas fisik juga berpengaruh pada tingkat kesehatan (Mahfud \& Yuliandra, 2020). Selain itu, aktifitas fisik atau latihan secara teratur menyebabkan paru-paru bekerja lebih efektif, dengan jumlah oksigen masuk yang bertambah ini akan membantu memudahkan kerja jantung. (Gumantan \& Fahrizqi, 2020). Dengan kinerja yang baik maka akan berdampak yang baik pada tubuh.

Berdasarkan hasil penelitian yang telah dilaksanakan bahwa tingkat kecemasan mahasiswa saat pandemi covid-19 berada pada 36,4\% merasa sangat resah dengan pandemi covid-19 yang terjadi, 34,1\% merasa resah. Hal ini, sesuai 
dengan penelitian dari (Fitria \& Ifdil, 2020) dengan hasil penelitian yang menyatakan tingkat kecemasan remaja $54 \%$ berada pada kategori tinggi. Hal disebabkan karena kurangnya informasi yang diperoleh remaja dan pola fikir remaja bahwa covid-19 sangat berbahaya. Faktor yang menyebabkan kecemasan selama pandemic Covid- 19 adalah kurangnya informasi mengenai kondisi ini, pemberitaan yang terlalu heboh di media masa ataupun media sosial terkait korban serta kurangnya literasi terkait dengan penyebaran dan mengantisipasi penularan covid-19. Informasi yang perlu diketahui bahwa covid-19 akan sangat berbahaya jika terjadi pada lansia dengan imun yang menurun dan pada seserang yang memiliki riwayat penyakit kronis seperti, diabetes, jantung, hipertensi, gangguan pernafasan. Kurangnya kesadaran masyarakat terhadap apa yang harus dilakukan dan tidak dilakukan untuk pencegahan. (Ilpaj \& Nurwati, 2020).

Terdapat beberapa aturan serta anjuran dari pemerintah untuk mengurangi serta mencegah terjadinya penularan covid-19. Pemerintah melalui Kementrian Kesehatan menghimbau kepada masyarakat untuk tetap menjaga jarak dan menghindari tempat-tempai keramaian (Phisical Distancing) serta menggunakan masker sebagai alat pelindung diri.(Kemenkes, 2020). Dengan pengetahuan yang baik terkait dengan kondisi pandemi dan bagaimana cara pencegahan serta menjaga tubuh agar tidak terdampak akan menurunkan tingkat kecemasan pada seseorang.

\section{SIMPULAN}

Penelitian ini memberikan gambaran bahwa saat ini tingkat kecemasan mahasiswa saat pandemi covid-19 masih tinggi yaitu 36,4\% merasa sangat cemas, $34,1 \%$ merasa cemas, 20,9 merasa tidak cemas, dan $9 \%$ merasa sangat tidak cemas dengan pandemi ini. Kecemasan ini dikarenakan ketakutan akan tertular virus ini dan berdampak pada proses pembelajaran mahasiswa serta ekonomi keluarga akan terganggu. Selama pandemi ini, menjaga imunitas tubuh sangat penting untuk menjalani kehidupan sehari-hari. Menjaga imunitas dilakukan dengan budaya melakukan hidup sehat, menjaga kebugaran dengan olahraga teratur, dan menghindari terjadinya stres. Perlu disadari bahwa virus ini sangat berbahaya, sehingga dalam beraktivitas sehari-hari harus sesuai dengan protokol kesehatan yang dianjurkan oleh pemerintah. 


\section{DAFTAR RUJUKAN}

Annisa, D. F., \& Ifdil, I. (2016). Konsep Kecemasan (Anxiety) pada Lanjut Usia (Lansia). Konselor, 5(2), 93. https://doi.org/10.24036/02016526480-0-00

Arti, G. A. N. W., Kanca, I. N., \& Suwiwa, I. G. (2018). Analisis Tingkat Kecemasan Siswa Kelas Viii Dalam Pembelajaran Senam Lantai Guling Lenting. Jurnal Pendidikan Jasmani, Olahraga Dan Kesehatan Undiksha, $5(2)$.

Dorland. (2010). Kamus Kedokteran Dorland (31st ed.). EGC.

Fadli, F., Safruddin, S., Ahmad, A. S., Sumbara, S., \& Baharuddin, R. (2020). Faktor yang Mempengaruhi Kecemasan pada Tenaga Kesehatan Dalam Upaya Pencegahan Covid-19. Jurnal Pendidikan Keperawatan Indonesia, 6(1), 57-65. https://doi.org/10.17509/jpki.v6i1.24546

Fitria, L., \& Ifdil, I. (2020). Kecemasan remaja pada masa pandemi Covid -19. Jurnal EDUCATIO: Jurnal Pendidikan Indonesia, 6(1), 1. https://doi.org/10.29210/120202592

Fitria, L., Neviyarni, Netrawati, \& Karneli, Y. (2020). Cognitive Behavior Therapy Counseling Untuk Mengatasi Anxiety Dalam Masa Pandemi Covid19. Al-Irsyad, 2859, 23-29. http://jurnal.uinsu.ac.id/index.php/alirsyad/article/viewFile/7651/3538

Gumantan, A., \& Fahrizqi, E. B. (2020). Pengaruh Latihan Fartlek dan Cross Country Terhadap Vo2Max Atlet Futsal Universitas Teknokrat Indonesia. Jurnal Sport-Mu Pendidikan Olahraga UM Jember, 1(1), 1-9.

Gumantan, A., Mahfud, I., \& Yuliandra, R. (2020). Tingkat Kecemasan Seseorang Terhadap PEmberlakuan New Normal dan Pengetahuan Terhadap Imunitas Tubuh. Sport Scienc and Education Journal, 1(2), 18-27.

Hammad. (2011). Peran Terapi Al-Qur'an terhadap Kecemasan dan Imunitas Pasien Hospitalisasi. Jurnal NERS, 4(2), 110-115.

Hengki, K., Metra, Y., \& Ilham, Z. (2018). Analisis Tingkat Kecemasan (Anxiety) dalam Menghadapi Pertandingan Atlet Sepak Bola Kabupaten Banyuasin pada PORPROV 2017. 17(2), 28-35.

https://covid19.go.id/peta-sebaran (diakses tanggal 29 Mei 2020)

Husdarta, H. J. S. (2010). Psikologi Olahraga. Bandung: Alfabeta.

Ilpaj, S. M., \& Nurwati, N. (2020). Analisis Pengaruh Tingkat Kematian Akibat Covid-19 Terhadap Kesehatan Mental Masyarakat Indonesia. Jurnal Pekerjaan Sosial, 3(1), 16-28.

Junaidi, \& Noor, Z. (2010). Penurunan Tingkat Kecemasan pada Lansia Melalui Terapi Musik Langgam Jawa. Jurnal Keperawatan Indonesia, 13(3), 195201. 
Kemenkes. (2020). Pedoman Pencegahan dan Pengendalian Corona Virus Disease (Covid-19). Kementerian Kesehatan RI.

Keppres No 11 Tahun 2020 Tentang Penetatapan Kedaruratan Kesehatan Masyarakat Corona Virus Desease-19 (COVID-19) (https://peraturan.bpk.go.id/Home/Details/135058/keppres-no-11-tahun2020, diakses 14 Juli 2020)

Keppres No 12 Tahun 2020 Tentang Penetapan Bencana Nonalam Penyebaran Corona Virus Desease-19 Sebagai Bencana Nasional (https://peraturan.bpk.go.id/Home/Details/135718/keppres-no-12-tahun2020, diakses 14 Juli 2020)

Mahfud, I., \& Fahrizqi, E. B. (2020). Pengembangan Model Latihan Keterampilan Motorik Melalui Olahraga Tradisional Untuk Siswa Sekolah Dasar. Sport Science and Education Journal Universitas, 1(1), 31-37.

Mahfud, I., \& Yuliandra, R. (2020). Pengembangan Model Gerak dasar Keterampilan Motorik Untuk Kelompok Usia 6-8 Tahun. 1(01), 54-66.

Mayasari, D., \& Pratiwi, A. (2009). Hubungan Respon Imun dan Stres Dengan Tingkat Kekambuhan Demam Tifoid pada Masyarakat Di Wilayah Puskesmas Colomadu Karanganyar. Berita Ilmu Keperawatan, 2(1), 13-18.

Mukhtar, P. D., \& Pd, M. (2013). Metode Praktis Penelitian Deskriptif Kualitatif. Jakarta: GP Press Group.

Nova, A., Sinulingga, A. R., \& Syahputra, A. (2020). The Level Of Parents Anxiety On Physical Education Activity At Lintang City Elementry School. Jp. jok (Jurnal Pendidikan Jasmani, Olahraga dan Kesehatan) , 3 (2), 156 164.

Nurseto, F. (2018). Psikologi Olahraga. Yogyakarta: Graha Ilmu.

Resti, I. B. (2014). Teknik Relaksasi Otot Progresif Untuk Mengurangi Stres Pada Penderita Asma. Jurnal Ilmiah Psikologi Terapan, 2(1), 1-20. https://doi.org/10.1017/CBO9781107415324.004

Setiawan, Atikno, W., \& Suratno. (2020). Analisis diskriminan faktor kecemasan karyawan menghadapi dampak Pandemi Covid-19: Kasus perusahaan manufacturing dan jasa survey. 12(2), 198-208.

Suardana, A. A. P. C. P., \& Simarmata, N. (2013). Hub Motivasi Belajar Dan Kecemasan Menjelang Ujian. Jurnal Psikologi Udayana, 1(1), 203-212. 